underlying abdominal pathology needing surgical intervention.

Liver function tests are often abnormal in patients with sepsis anywhere; an elevated serum vitamin $B_{12}$ level is a useful pointer to a source in the liver. ${ }^{3}$ In the three Leicester patients in whom vitamin $B_{12}$ was measured, two had grossly elevated levels and the third was at the upper limit of normal. We recommend vitamin $B_{12}$ estimation in patients with unexplained pyrexia as delay in the diagnosis of a liver abscess, as you point out, is usually fatal.

J P NeOptolemos D S MACPHERSON D P FOSSARD

University Department of Surgery,

Leicester Royal Infirmary,

${ }^{1}$ Maher JA, Reynolds TB, Yellin AE. Gastroenterology $1979 ; 77: 618-22$

McFadzean AJS, Chang KPS, Wong CC. Br f Surg 1953;41:141-52.

Bre G, Caughey DE, Mollin DL, Booth CC. Br Med f 1966;i:382-7.

\section{Surgical treatment of prolapsed lumbar discs}

SIR,-I would certainly agree with $\mathrm{Mr}$ Keith Norcross (26 April, p 1123) that radiography should be reserved for certain well-defined indications in apparent "prolapsed lumbar disc". However, I would like to take further issue with your leading article "Surgical treatment of prolapsed lumbar discs" (22 March, p 814).

Firstly, not all back pains with sciatica originate from prolapsed lumbar discs. ${ }^{1-3}$ Irritant fluid injection into the lumbar facet joints gives pain indistinguishable from sciatica. $^{45}$ Secondly, positive neurological signs do not necessarily indicate pressure on a nerve root. ${ }^{4}$ Weakness, for instance, of hip abductors or foot dorsiflexors may often occur as a pain-inhibition reflex. Thirdly, "lifting with a bent back" is quoted by you as the important origin of back injury. Careful history in acute back pain often elicits a twisting component in the injury. This is important with regard to management. Lastly, you advocate "strict bed rest" as the mainstay of conservative therapy. No one doubts the value of rest but is bed rest alone the first-line routine treatment?

In a twisting injury of the spine those facet joints able to take up the rotational strainthat is, mainly the thoracic posterior spinal joints-do so. The continuation of the injurious strain, especially when weak or unexpecting muscles are improperly protective, tends to twist the next most vulnerable site. It is biomechanically and anatomically sound to suggest that this may be a lower lumbar facet joint. Mild subluxation may be locked in that position by muscle spasms, and neurological signs and symptoms may ensue for reasons already stated. If this argument is valid, then reduction of the subluxation may be expected to produce an immediate alteration of signs and symptoms. My experience as a junior at Warrington was to see a large majority of acute "prolapsed-lumbar-disclike" back pains miraculously cured, with a loud and satisfying clunk, by a twisting type of manipulation.

My scepticism vanished at my first successful manipulation, half an hour after being shown the technique. I find it incredible that the majority of orthopaedic consultants still regard manipulation as quackery. NHS financial resources can no longer afford such obstinacy.

\section{Royal Liverpool Hospital,}

LAURENCE WOOD

Royal Liverp
Liverpool

1 Barbor RCB. Br Med F 1978;ii:566.

2 Bourne IHJ Br Med f 1978;ii:566-7.

${ }^{3}$ Chormley PK. F AMA 1933;101:1773-7. Mooney V, Robertson, JA. Clin Orthop 1976;115
149-56.

${ }^{5}$ Hirsch D, Ingelmarcke B, Miller M. Acta Orthop Scand 1963;33:1-17.

\section{Anglo-French contrasts in medical practice}

SIR,-Having spent two months in Grenoble Medical School, I was interested to read Dr A W M and J M T Porter's observations on French medicine (26 April, p 1109). Whereas I would agree with many of their observations, I would like to offer different interpretations.

Fiscal factors not only determine the style of practice, but also keep waiting lists to a minimum. The mechanism for the latter is quite simple: if a specialist cannot offer treatment within a week, the patient will find one who can. The specialist who offers a delay will soon acquire a poor reputation and his business will decline accordingly. The waiting list for surgery in Grenoble was one week.

Table II exposes the burden of committee meetings carried by British specialists. When viewed in the light of our disgraceful waiting list it must be a strong point in favour of ambitious pruning of the rambling NHS administration.

The doctor-patient relationship is mentioned on page 1110. The authors may have noticed that Provence is about 1000 miles south of London and often enjoys hot weather. Indeed, this may have been a significant factor $(p \leqslant 0.001$ ?) in choosing the location for this study. The wearing of threepiece suits and ties would prompt cries of "Mad dogs and Englishmen..." from the waiting room. We have a lot to learn from our neighbours across the channel.

A J France

Godmanchester Huntingdon PE18 8AQ

\section{Community medicine and community physicians}

SIR,-It is sad to learn from Drs K M Parry and Helen E Zealley (10 May, p 1193) that community physicians in Scotland are facing formidable difficulties, and lack the sympathy of and an understanding of their role by colleagues in other specialties.

I would beg such community physicians (1) to get on with their job-to look behind the statistics, to provoke other doctors, nurses, lay administrators, the health authorities or boards, the DHSS, and the community they serve; (2) to stop building their own empires; (3) to curb their own verbosity; (4) to stop looking for love and adoration; (5) to manage -if they are on management teams jointly, otherwise individually.

Perhaps some community physicians in England too suffer from the Scottish disease? Not too many, I hope. As district community physician, I do not expect to be loved by everyone all the time. I hurl brickbats and hand out bouquets. I am bound to be treated similarly.

Peterborough, Cambs PE3 6PJ

$\mathrm{J}$ K ANAND

\section{Reimbursement for ancillary help by relatives}

SIR,-If reports are correct, then GPs who employ their wives or husbands who are nurses are to be given the $£ 925$ allowance, as are single-handed rural GPs. This is insulting to GPs and their spouses. How dare the GMSC and DHSS negotiators insult professional men and women?

I am worth $£ 6024$ a year to our practice and the GMSC and DHSS come to an agreement to allow our practice $£ 925$. Not $70 \%$ (that is, f4216), which is paid for one of our other practice nurses, doing exactly the same work. This is blatant discrimination. It is outrageous.

My husband, at present a BMA member, hopes the LMC Conference members will show their anger and displeasure by passing overwhelmingly a motion this month that SFA 52.2 be changed so that all staff are included in the scheme for $70 \%$ reimbursement.

Chard, Somerset TA20 1QL

M J Glanvill

\section{The BMA division}

SIR,-The $B M f$ being an irregular arriver lately, I have only just read $\mathrm{Mr}$ Norman Ellis's interesting note (3 May, $p$ 1151) on how he finds divisions: very varied, it seems. $\mathrm{He}$ goes on to ask some questions about what should be done to maintain a viable local unit but-very wisely-offers no single cure. Having observed, both as an observer at the centre and as an attender locally, the general (for there are exceptions) slow asthenia of divisions, I would like to throw this idea at the Organisation Committee.

All the GPs of a county have a common interest - but rarely do they meet all together; they elect a representative LMC by post. All the consultants, HJS doctors, and community physicians in a region have a similar common interest-and serve it by electing a representative committee, not by general meetings. Indeed the same pattern exists throughout civic and parochial life as well.

Is it not time that we abandon (save where its members really want it and will support it) the division per se as a continuing presencea body with rules which require it to meet quarterly, and so on ? Instead, let the members resident in its area elect-possibly biennially or triennially-a representative committee. This should be done by post, and by a single transferable vote; this latter would probably obviate any need for craft-reserved seats, but if such "sheep and goatery" is thought desirable, it can be built into a single transferable vote ballot count. The executive committee would have a continuing responsibility both to its electorate and to the Council. Like the other representative committees mentioned, it would call full general meetings of members when there was need; it could, as now, organise educational meetings and social gatherings, if that were the clear desire of the electorate.

Surely such a restructuring-even if some would see it as a council of despair (though I do not)-is to be preferred to the farce of the AGM attended by the members of the 